\title{
THE INFLUENCE OF MANDIRI SHARIA BANK SAVINGS PROMOTION ON INTEREST SAVING PEOPLE OF PALEMBANG CITY
}

\author{
Nawawi Zaidan* \\ University of Sjakhyakirti, Palembang, South Sumatra, Indonesia \\ Supriadi' Azizah, Wadjdi Farid, Har M. Senen, Sadikin Ali \\ Institute of Economic Science APRIN, Palembang, South Sumatra, Indonesia \\ Syaeful Windiarto \\ Raden Fatah State Islamic University, Palembang, South Sumatra, Indonesia \\ *E-mail: zaidannawawi0809@gmail.com
}

\begin{abstract}
The aim of this study to find out how much interests in saving people in the city of Palembang, especially saving in a Sharia-based regional bank, namely the Mandiri Sharia Banking. This research was conducted for two months, this study used primary data by distributing questionnaires, location of the study was in the city of Palembang and data analysis in this study by using multiple linear regressions. The results of this study were advertisements have an effect on peoples' saving interest on Mandiri Sharia Banking Palembang.
\end{abstract}

\section{KEY WORDS}

Promotion, advertisement, publicity, sales promotion, personal selling, saving.

Competition banking industry in Indonesia is increasingly tight. Where the development of the number of private banks and also Islamic banks continues to increase rapidly. Competition in the banking industry in Indonesia is increasingly tight. Where the development the number of private banks and also Islamic banks continues to increase rapidly such as Bank Muamalat, CIMB Bank, Bank Mandiri Syariah, BRI Syariah, and other banks that continue to emerge. The occurrence of such competition means that there have also been changes in promotional strategies in order to optimize banking services. The increasing prospect of the banking industry requires banking institutions to have the right strategy in marketing their banking products and services. One form of supporting marketing strategy is the use of a promotional mix. It is expected that by implementing the right promotion strategy through advertising, sales promotion, personal selling, public relations, and direct marketing the company can immediately reach the desired target market and at the same time create a good image for the company. In line, with the development and growth of the Shariah banking industry, Islamic Commercial Banks (BUS) compete fiercely to attract the public to save at their respective banks. Various strategies were used so that people who had saved became loyal and to attract other banks to move their deposits from other banks to the bank. One strategy that is carried out is to promote by offering products owned by a bank to the public through print or electronic media and so on (Ortega and Alhifni, 2017).

The diversity of products and services offered by banking institutions not only provides wider opportunities for consumers to choose a banking institution that suits their needs, but also raises doubts because there are too many choices offered by these banking institutions. Consumer decision making processes in purchases vary depending on the type of purchasing decision. The decision to buy a motorbike, bath soap, car, clothes, buy credit and others are very different things. Purchases that are complex and expensive goods often lead to more buyer considerations than purchases that are not complicated and inexpensive. On the other hand, consumers' penchant for seeking information from various sources before deciding to save in a bank are some things that must be considered by the company. 
Therefore, financial institutions need to conduct field surveys to monitor consumer behavior in making decisions that are considered if they will save at the bank. Based on the phenomena and previous research that the researchers have explained and mentioned above, the researcher will submit a research proposal with the title of the influence of the savings promotion of sharia independent banks on the interest in saving people in Palembang.

\section{LITERATURE REVIEW}

According to Stanton (2013), promotion is an element in the company's marketing mix that is utilized to notify, persuade, and remind about the company's products. Promotion becomes a medium of information to recognize all things related to products that the company will offer to consumers. The effectiveness of sales promotion activities will greatly determine the product image and corporate image in the eyes of the public, especially consumers, in the end will greatly affect the level of consumer demand for the products offered by the company. That is why the activity of promoting goods to be sold, including the selection of advertising media in accordance with the trading section, is a very important activity for an entrepreneur. According to Swastha and Irawan (2008), Promotion is a flow of information or persuasion in one of direction to direct an individual or organization to actions that create exchange in marketing. Promotion is one of the variables in the marketing mix that is very important to be implemented by companies in marketing service products.

Advertising does not merely convey information about a commodity (object or service), but has the nature of encouraging and persuading that we like, choose and buy it. According to Kusumawati (2010), Advertising is an activity of delivering news delivered on the order of the party who wants the product or service in question to be liked, chosen and purchased. Sawant (2012) in his research, advertising provides support to prospective consumers who have doubts about buying a product, so that the doubts of prospective customers will decrease and eventually will become convinced and buy the product. Advertising must be carried out on a scale large enough to make an effective impression on the market. Advertising is also all forms of non-personal presentation and promotion of the idea of goods or services by certain sponsors that must be paid. Advertising is a cost-effective way to deliver messages, to build brand perceptions or to educate people (Kotler and Keller, 2012).

Sales promotion is a short-term incentive to encourage desire and to try or buy a product / service (Kotler and Armstrong, 2008). Sales promotion is an activity that is an invitation, provides added value or an incentive to buy products, to retailers, sellers, or consumers. This means that sales promotions are consumer-oriented directed at end users of goods and services. Companies use sales promotion tools to create stronger and faster responses. Sales promotions can also be used to encourage sales that are sluggish and dramatize offers, especially if for example it is done by means of a sales demonstration.

Publicity is the driving force of non-personal demand for a product, service or idea by using commercial news in the mass media and sponsors are not directly burdened with a fee (Harini, 2008). Publicity as a form of communication management that functions to influence the company's image which is usually focused on positive things from the company concerned (Onditi, 2012). Publicity is an editorial space in all media that is read, seen or heard to help achieve sales goals and not be paid. Publicity is also called public relations. A news, statement or commentary in the media, both print and electronic media that can be trusted and familiar is very influential for the reader on the impression of the company and its goods.

According to Kotler and Keller (2012) stated that the implementation of personal selling involves the main role of the salesperson who in direct implementation faces the buyer, so that a salesperson does not only function as a salesperson of the company's products but must act as an ambassador or company representative. Salespeople are trained with highpressure sales techniques such as selling encyclopedias or cars. These techniques include exaggerating excess products, criticizing competing products, using sophisticated presentations, marketing themselves, and offering an agreement to get orders. Personal 
selling, among others, according to Buchari (2010) states that personal selling are oral presentations in a conversation between one person or more with prospective consumers who aim to create sales.

Consumer behavior is actions that are directly involved in obtaining, determining products and services including the decision-making process of saving and following these actions (Tjiptono, 2002). Interest is the tendency in an individual to be interested in something object or like something (Suryabrata, 2006). Interest will arise if we have a form of choice or view of an object or object that can be reached by the senses or that is born of individual thoughts.

\section{METHODS OF RESEARCH}

The sample is a portion of the population or in mathematical terms can be referred to as a subset or subset of the population (Sugiyono, 2014). The population in the study was the entire community in the city of Palembang. The analysis aims to determine the relationship between the dependent variable and the independent variable. In this study, researchers used multiple linear regression analysis, then presented in the form of a frequency distribution table. The following regression equation: $a=$ Constant; $Y=$ Interest saving; $X_{1}=$ Advertisement; $X_{2}=$ Publicity; $X_{3}=$ Sales promotion; $X_{4}=$ Personal selling; $b_{1}=$ multiple linear regression coefficient between $X_{1}$ and $Y ; b_{2}=$ multiple linear regression coefficients between $\mathrm{X} 2$ and $Y ; b_{3}=$ multiple linear regression coefficient between $X 3$ and $Y$; $\mathrm{b}_{4}=$ multiple linear regression coefficient between $\mathrm{X} 4$ and $\mathrm{Y} ; \mathrm{e}=$ error term.

\section{RESULTS AND DISCUSSION}

The following are the results of the analysis of the normality test using the KolmogorovSmirnov test that researchers have done:

Table 1 - Normality Test with Kolmogorov-Smirnov Test

\begin{tabular}{|c|c|}
\hline Model & Value \\
\hline Test Statistic & .057 \\
\hline Asymp. Sig. (2-tailed) & .200 \\
\hline
\end{tabular}

Source: Research Data, Processed 2019.

Kolmogorov-Smirnov test value obtained is 0,057 , so it can be concluded that the data is normally distributed (Ghozali, 2009). Based on the results of the analysis, the classic assumption of autocorrelation is obtained as follows:

Table 2 - Autocorrelation Test with Durbin Watson

\begin{tabular}{|c|c|}
\hline Model & Value \\
\hline Durbin Watson & 1,848 \\
\hline Probability & 0,000 \\
\hline
\end{tabular}

Source: Research Data, Processed 2019.

The Durbin Watson value is 1.848 , this value is between -2 to 2 , meaning that there is no autocorrelation problem (Santoso, 2006). Good regression models should not occur between correlations of independent variables (no multicollinearity):

Table 3 - Multicollinearity Test with Tolerance and VIF

\begin{tabular}{|c|c|}
\hline Model & Value \\
\hline Advertisement & 1.432 \\
\hline Publicity & 1.657 \\
\hline Sales Promotion & 1.409 \\
\hline Personal Selling & 1.259 \\
\hline
\end{tabular}

Source: Research Data, Processed 2019. 
Based on table 4.7, it is known that the tolerance value of all independent variables is> 0.10 . Whereas for VIF values all independent variables $<10.00$. Based on the criteria in decision making, it can be concluded that there is no multicollinearity (Ghozali, 2009).

Heteroscedasticity tests that have been carried out, with the following results:

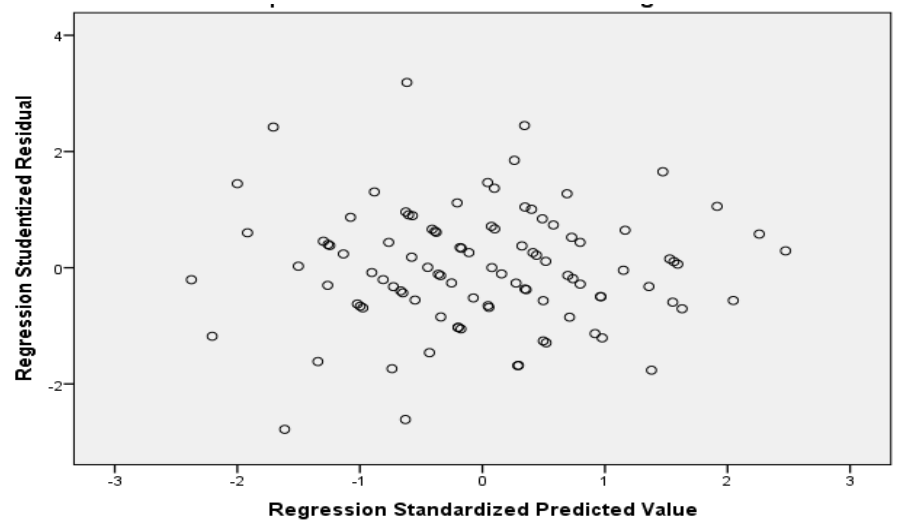

Figure 1 - Heterocedasticity Test with Scatterplots (Source: Research Data, Processed 2019)

Based on the picture above, the pattern of the analysis results spread, not forming a group such as zigzag, the circle in the middle and gathering around 0 to - 0 , which means there is no problem of heterocedasticity.

The $F$ test is used to determine the effect of independent variables together (simultaneous) on the dependent variable if significant means the relationship that occurs can apply to the population.

Table 4 - Simultaneous Influence Test (Test F)

\begin{tabular}{|c|c|c|c|c|c|c|}
\hline \multicolumn{2}{|c|}{ Model } & Sum of Squares & df & Mean Square & F & Sig. \\
\hline \multirow{3}{*}{1} & Regression & 365.739 & 4 & 91.435 & 43.647 & .000 \\
\cline { 2 - 7 } & Residual & 199.011 & 95 & 2.095 & & \\
\cline { 2 - 8 } & Total & 564.750 & 99 & & & \\
\hline
\end{tabular}

Source: Research Data, Processed 2019.

From table 4 above, the value of Fcount is 43,647 with a probability value $(\mathrm{Sig})=$ 0,000 . The value of Fcount $(43,647>$ of Ftable $(2,11)$, while the value of sig is smaller than the probability value of 0,05 or $0,000<0,05$, based on the results of the analysis it can be concluded that there is a significant influence between advertising, publicity, sales promotion and personal selling in general towards the interest of saving people.

Testing can also be with the t test or t-test, which compares the count with t-table. If $t$ table $<\mathrm{t}$ count $<\mathrm{t}$ table, then $\mathrm{H} 0$ is accepted, that is, the independent variable has no effect on the dependent variable, if $t$ count $>t$ table or - $t$ count $>-t$ table, then $\mathrm{HO}$ is rejected which means the independent variable has a significant effect on the independent variable.

Table 5 - Inter Variable Partial Test

\begin{tabular}{|c|c|c|}
\hline Variable & T Value & Sig. \\
\hline Advertisement & 6.988 & .000 \\
\hline Publicity & 5.114 & .000 \\
\hline Sales Promotion & .123 & .902 \\
\hline Personal Selling & .361 & .719 \\
\hline
\end{tabular}

Source: Research Data, Processed 2019.

If $\mathrm{t}$ count> $\mathrm{t}$ table, then $\mathrm{HO}$ is rejected and $\mathrm{Ha}$ is accepted and vice versa $\mathrm{t}$ count $<\mathrm{t}$ table, then $\mathrm{HO}$ is accepted and $\mathrm{Ha}$ is rejected. The number of $\mathrm{t}$ table with the provisions $\mathrm{dk}=\mathrm{n}-\mathrm{k}(100-8)=92$ observations. From these provisions, a number from t table is 1.986. 
The influence of advertising on interest in saving, the value of $t$ count 6.988> from 1.986, with a significance value of $0.000<0.05$, then the conclusion is $\mathrm{H} 1$ accepted or the first hypothesis is accepted, which means that advertising affects the interest in saving. Based on the results of the analysis, the research is in accordance with the Mahmudah (2014) study which found a relationship between advertising to the customer's saving interest.

The influence of publicity on interest in saving, the value of t count is $5.114>1.986$, with a significance value of $0.000<0.05$, then the conclusion is $\mathrm{H} 2$ is accepted, or the second hypothesis is accepted, which means publicity influences the interest in saving. Based on the results of the analysis that has been carried out, this result is consistent with the research of Maisya (2013) which states that advertising and public relations (publicity) have a significant influence on saving decisions.

The effect of sales promotion on interest in saving, sales promotion has a value of $t$ count $0.123<1.986$, with a significance value of $0.902>0.05$. So, $\mathrm{H} 3$ is rejected or the third hypothesis is rejected, which means that the sales promotion variable does not affect the interest in saving. The results of this study are in accordance with Pulungan's research (2011) which concluded that promotion does not affect the customer's saving decisions.

The effect of personal selling on saving interest, personal selling has a value of $t$ count $0.361<1.986$, with a significance value of $0.719>0.05$. Then the conclusion $\mathrm{H} 4$ is rejected or the fourth hypothesis is rejected, which means that the personal selling variable does not affect the interest in saving. Based on the results of the analysis, previous studies that are in accordance with the results of the researchers namely Yudhiartika and Haryanto (2012) personal selling and display studies have no significant effect on the variable awareness of the interest in buying product brands.

\section{CONCLUSION}

Based on the results of this study, it can be concluded that advertising influences people's saving interest, meaning that the more attractive advertisements offered to the public, the advertisement will affect the community's saving interest. Publicity influences people were saving interest, with the bank's relationship with the community, will have a reciprocal effect on the company's image. Sales promotion has no effect on people's interest in saving, the possibility of a sales promotion is less effective, by distributing brochures, and peoples' interest in reading leaflets is certainly reduced, especially in a digital era like this. Personal selling also have no effect on interest in saving, direct sales in the form of services are less effective when viewed in terms of time and energy, because people who are actually busy with their works.

\section{REFERENCES}

1. Ghozali, Imam. 2009. Aplikasi Analisis Multivariate dengan Program SPSS Edisi 5. Semarang: Badan Penerbit Universitas Diponegoro.

2. Harini. 2008. Makroekonomi Pengantar. PT Gramedia Pustaka Utama: Jakarta.

3. Kotler, Phillip. 2008. Manajemen Pemasaran Edisi Keenam Jilid 2. Jakarta: Erlangga.

4. Kotler, Philip and Armstrong Gary. 2008. Prinsip-Prinsip Pemasaran Edisi Ketiga Belas Jilid Kedua. Jakarta: Erlangga.

5. Kotler, Philip and Kevin Lane Keller. (2012). Manajemen Pemasaran Alih Bahasa Benyamin Molan, Edisi Ketiga Belas. Jakarta: Indeks.

6. Kusumawati, 2010. Analisis Pemakaian Gaya Bahasa pada Iklan Produk Kecantikan Perawatan Kulit Wajah di Televisi. Skripsi. Surakarta: Universitas Sebelas Maret.

7. Mahmudah, Arifatul. 2014. Pengaruh Periklanan, Promosi Penjualan and Hubungan Masyarakat Terhadap Keputusan Menabung (Studi Kasus KJKS Dana Barokah Muntilan). Skripsi Prodi Keuangan Islam, Fakultas Syariah and Hukum Universitas Islam Negeri Sunan Kalijaga Yogyakarta. 
8. Maisya, Fitri. 2013. Pengaruh Periklanan, Promosi Penjualan and Hubungan Masyarakat Terhadap Keputusan Menabung Di PT. Bank Negara Indonesia Cabang Bukittinggi. Jurnal Manajemen. Vol. 02, No. 1, 2013.

9. Onditi, Arvinlucy Akinyi, Moses N. Oginda, Isaac Ochieng, and Willis Oso. (2012). Implications of Service Quality on Customer Loyalty in the Banking Sector. A Survey of Banks in Homabay County, Kenya. International Journal of Business and Social Science, Vol. 3 No. 21, November 2012.

10. Ortega D. and Alhifni A. 2017. Pengaruh Media Promosi Perbankan Syariah Terhadap Minat Menabung Masyarakat di Bank Syariah. Jurnal Equilibrium: Jurnal Ekonomi Syariah, Volume 5, Nomor 1, 87-98. Bogor.

11. Pulungan. Anisa. 2009. Analisis Faktor-faktor Yang Mempengaruhi Nasabah Untuk Menggunakan Produk Jasa PT. Bank Negara Indonesia (Persero), Tbk Cabang Syariah Medan. Skripsi, Departemen Manajemen, Universitas Sumatera Utara Medan.

12. Santoso, Singgih. 2006. Buku Latihan SPSS Parametrik. Jakarta: Gramedia.

13. Sawant, R. P. (2012). Impact of advertising on brand awareness and consumer preference (with special reference to men's wear). IOSR Journal of Business and Management, 5(6), hlm.54-61.

14. Stanton, Wiliam J. 2013. Prinsip Pemasaran. Alih Bahasa oleh Buchari Alma. Jilid Satu. Edisi Sepuluh. Jakarta: Erlangga.

15. Suryabrata, Sumadi. 2006. Psikologi Kepribadian. Jakarta: PT. Raja Grafindo Persada.

16. Swastha, Basu and Irawan. 2005 Manajemen Pemasaran Modern. Edisi Kedua. Cetakan Ke-tigabelas. Yogyakarta: Liberty Offset.

17. Tjiptono, Fandy and Gregorius Chandra. (2002). Service, Quality, \& Satisfaction. Yogyakarta: Andi Offset.

18. Yudhiartika, Dian dan, Jony Oktavian Haryanto. 2012. Pengaruh Personal Selling, Display, Promosi Penjualan Terhadap Kesadaran Merek and Intense Membeli Pada Produk Kecantikan Pond's. Buletin Studi Ekonomi. Vol. 17 No. 2 Agustus 2012. 